\title{
Post-Fire Recovery of Vegetation and Diversity Patterns in Semiarid Pinus halepensis Mill. Habitats after Salvage Logging
}

\author{
Daniel Moya ${ }^{1, * \mathbb{D}}$, Javier Sagra ${ }^{1}\left(\mathbb{D}\right.$, Manuel Esteban Lucas-Borja ${ }^{1}(\mathbb{D}$, \\ Pedro Antonio Plaza-Álvarez ${ }^{1}$, Javier González-Romero ${ }^{1}$, Jorge De Las Heras ${ }^{1}$ (D) \\ and Pablo Ferrandis 1,2 (D) \\ 1 Escuela Técnica Superior de Ingenieros Agrónomos y Montes, Universidad de Castilla-La Mancha, \\ Campus Universitario s/n, 02071 Albacete, Spain; javiersagracozar@gmail.com (J.S.); \\ ManuelEsteban.Lucas@uclm.es (M.E.L.-B.); pedro.plaza@uclm.es (P.A.P.-Á.); \\ Javier.GRomero@uclm.es (J.G.-R.); jorge.heras@uclm.es (J.D.L.H.); pablo.ferrandis@uclm.es (P.F.) \\ 2 Botanical Institute, University of Castilla-La Mancha, Botanic Garden of Castilla-La Mancha, \\ Avda. de la Mancha s/n, 02006 Albacete, Spain \\ * Correspondence: Daniel.Moya@uclm.es
}

Received: 27 October 2020; Accepted: 14 December 2020; Published: 17 December 2020

\begin{abstract}
After wildfires, emergency actions and post-fire management are implemented to mitigate fire damage. Salvage logging is a tool often applied to burned stands, but despite being a post-fire forest management tool to restore ecosystem functions, its ecological effects remain poorly understood. In the Mediterranean Basin, where land use and land-use change are bringing about changes in drought periods and fire regimes, optimal treatments should be included in adaptive management in order to increase resilience and reduce vulnerability. In July 2012, a mid- to high-burn severity fire burned almost 7000 ha of an Aleppo pine forest (Pinus halepensis Mill.) in southeastern Spain. Five years later (late spring 2017), we designed an experimental study to monitor four stand categories on a burn severity basis (unburned mature stands, low-burn severity stands, and high-burn severity stands) and a salvage logging operation carried out 6 months after the fire in high-burn severity areas. We set 60 circular plots (15 in each treatment scenario) and 180 linear transects ( 3 per plot, 45 per scenario) to check the ecological facilitation of pine trees and snags (canopy size and/or perch effect). We estimated plant alpha diversity (floristic richness, abundance and dominance indices) and post-fire plant recovery (pine recruitment and adaptive traits). Fire depleted the system's diversity, but in low-severity burning areas some basic functions remained intact (e.g., soil protection). We found that high-burn severity very negatively impacted ecosystem functions through the removal of duff and litter leaving unprotected soil. Collecting wood reduced pine regeneration and growth, which was considerable in the areas that suffered high-burn severity. The burned snags did not appear to act as perches resulting in seed dispersal. Obligate seeders were determined to be an efficient strategy for facing high-severity fires, whereas resprouters response showed no clear burn severity pattern despite being present in all the scenarios. Therefore, salvage logging did not affect the recovery of some ecosystem properties/features (such as plant total cover or litter cover), although retaining dead pines facilitated pine regeneration. Thus, leaving snags in areas affected by high-burn severity in ecosystems mainly modelled by fires is proposed. However, the ecosystem response could be widely variable and influenced by local abiotic factors, so restoration might not be as effective as in the current proposal.
\end{abstract}

Keywords: pine recruitment; wildfire recovery; post-fire management; pine saplings; alpha diversity 


\section{Introduction}

Wildfire is a natural phenomenon in many ecosystems around the world that shapes the community and structure of ecosystems and was used by our earlier ancestors [1]. Mediterranean landscapes and terrestrial ecosystems have been shaped by historical fire regimes which can be considered unsustainable in recent decades due to changes in not only land use and climate [2], but also in forest policies, such as fire suppression [3]. In the Mediterranean Basin, fire has been considered an important driver of soil formation and erosive processes [4]. However, interactions between fire and other disturbances, such as drought and pest attacks, increase the disturbance damage and the vulnerability of forest ecosystems [5].

The resilience of forest ecosystems in fire-prone areas determines their ability to recover functions after disturbance, such as plant cover, diversity, and structure [6]. The goal of adaptive forest management, especially in Mediterranean semiarid areas, is to reduce vulnerability and strike a balance in the ecosystem to allow it to cope with new forthcoming extreme disturbances [7]. Natural post-fire recruitment and plant diversity have been inversely related to burn severity (sensu [8]), although recurrence and soil interaction can influence that response [9,10]. For Mediterranean pine habitats, plant communities are adapted to fire regimes characterized by mid to low severity and low recurrence (more than 25 years) [11-13]. The direct negative impacts of wildfires on flora, fauna, and soil have been well studied [14-16], but valuations on ecosystem services are still poor [17], even if there are certain ecological and socio-economic benefits of sustainable fire regimes [1,18]. Post-fire management may mitigate (or upsurge) impacts on functions, such as variation in carbon flux [19], soil protection or plant diversity [20].

Fire-adapted plant communities are characterized by adaptions to a fire regime, with resprouting being the most common post-fire regeneration trait (from protected buds), although conspicuous seed germination (from a fire-resistant seed bank in combination with fire-cued germination) is also common [1]. For serotinous pine species, the aerial seed banks enclosed in pine cones are insulated from the heat of flames [21], and germination is triggered by post-fire conditions [22-25]. Pinus halepensis Mill. (commonly named Aleppo pine) is a broadly distributed species in the western Mediterranean Basin [26] that shows early cone production (to reduce the immaturity risk) and a dual reproductive strategy including an aerial seed bank within persistent closed serotinous cones [27]. Despite these adaptations, changes in fire regime and lack of forest management reduced the productivity and serotiny of Aleppo pine stands, which could promote vulnerability [28,29].

In Aleppo pine stands, salvage logging reduces the recruitment of pine trees and increases the vulnerability of the plant community to drought periods [30,31]. However, low-intensity cutting combined with the remaining woody debris mitigates the negative impact of salvage logging on flora and soil [32,33], and even on fauna by increasing rodent activity [34]. Even the release of deadwood on the ground plays a facilitative role in regeneration recruitment [35]. In fire recurrence scenarios within short-time intervals (<15 years), high-intensity salvage logging has been proven to be inadvisable for sustainable management, but if fine and coarse woody debris remain after manual harvesting, material legacies help the natural regeneration of trees and enhance ecosystem resilience to the next disturbance [36]. Therefore, post-fire management can determine ecosystem dynamics by facilitating the natural recovery of vegetation composition and structure [5]. Also, a proper post-fire restoration could reduce vulnerability to new extreme events, reducing the time left for the immaturity risk period and accelerating the recovery of pre-fire functions and ecosystem services [37].

For all these reasons, we evaluated the ecological facilitation associated with the size of trunks and canopies of snags after a major wildfire in the southeastern Iberian Peninsula, combined with the effect of burn severity and post-fire management on mid-term vegetation recovery. We hypothesized that, in the mid-term, higher burn severity would promote alpha diversity and reduce the density and height of pine saplings. In semi-arid Mediterranean ecosystems, where pine density and plant diversity after fires are often very low, high-intensity salvage logging after fire can further reduce their values, which could be improved if old snags are retained due to ecological facilitation for natural 
regeneration. Our preliminary observations in high-burn severity stands allowed us to hypothesize that non-intervention related to biomass removal would mitigate fire effects and facilitate pine seedling survival in the microclimate generated by wood debris and snag trees.

\section{Materials and Methods}

\subsection{Study Area}

The study area lies in the southeastern Iberian Peninsula (Donceles mountain forest), which has remained unburned for at least 80 years (digital cartography provided by [38]). In July 2012 (July 1-6), a wildfire burnt 6870 ha (Figure 1), with the ignition point located at 608309 E, 4254211 N; ETRS89 UTM 30N. The summarized weather conditions during the burning dates were as follows: maximum temperature range: $31-37^{\circ} \mathrm{C}$; mean air humidity: $30 \%$; and mean wind speed: $1-3 \mathrm{~m} \mathrm{~s}^{-1}$ (gusts of $\left.15 \mathrm{~m} \mathrm{~s}^{-1}\right)$.
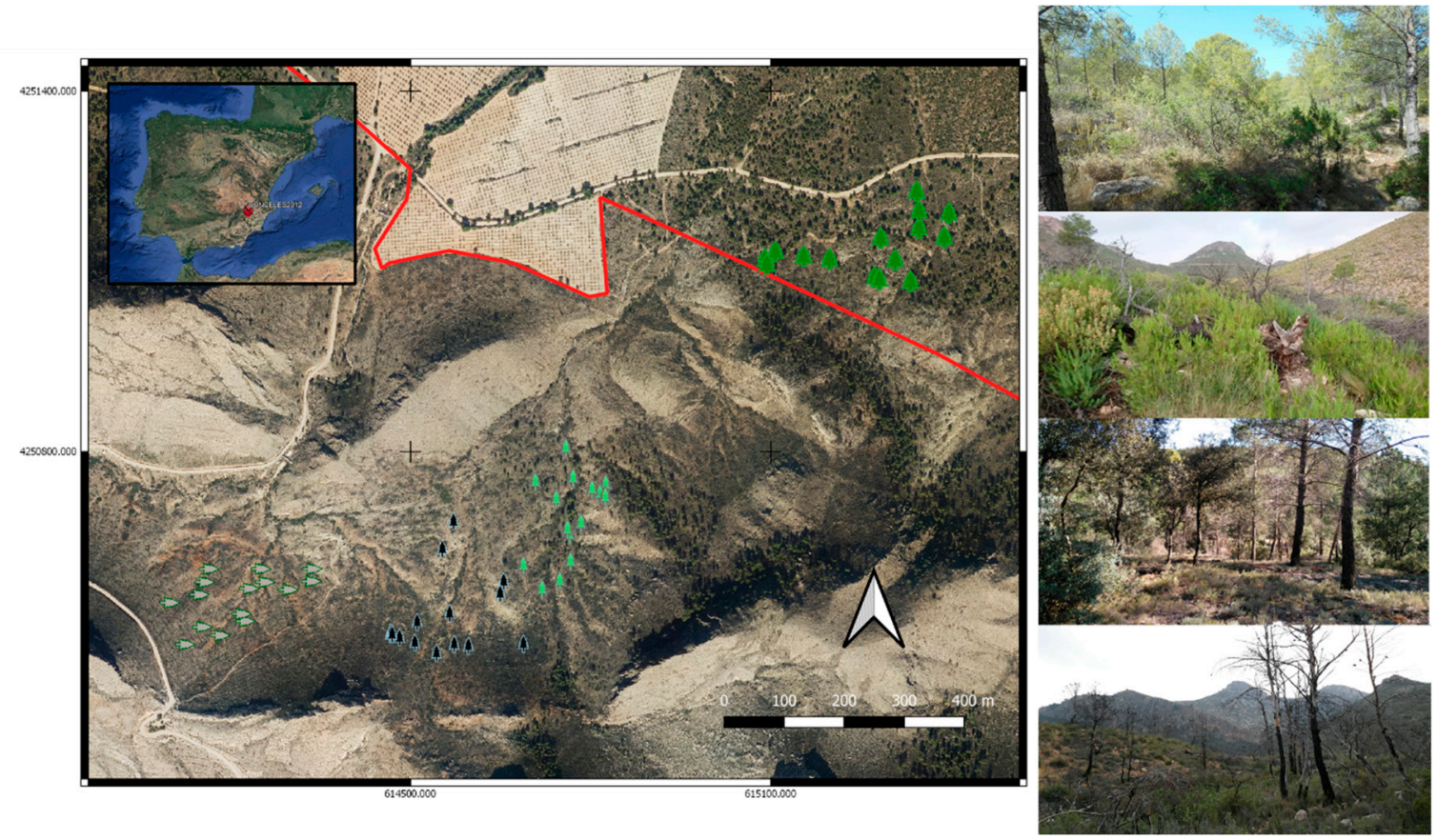

Figure 1. Location of the wildfire in the southeastern Iberian Peninsula (almost 6500 ha burned in the summer of 2012). Plots sampled in June 2017 were set in unburned natural Aleppo pine stands (UB; dark greenish-pine tree icon), low-burn severity (LS; light greenish-pine tree icon), high-burn severity unmanaged (HS; blackish-pine tree icon), and high-burn severity with post-fire salvage logging (HSSL; greenish-fallen pine tree icon).

The predominant climate was characterized as semiarid Mediterranean (dry period from June to September, with relative humidity <50\%). According to the Köppen-Geiger classification [39], it is a cold semi-arid climate (type "BSk") located on the upper meso-Mediterranean bioclimatic belt. The mean annual precipitation and temperature were $286.30 \mathrm{~mm}$ and $15.96{ }^{\circ} \mathrm{C}$, respectively (data from 1992-2017; provided by the Spanish Meteorological Agency), although annual rainfall was slightly higher from 2012 to 2017 [40]. Soils were classified as Aridisols (Lithic Haplocalcids) (i.e., calcareous soils with no water availability for plants for long periods ( $>90$ days)) [41]. The main landforms were composed of rocky slopes formed with dolomitic limestone (300-800 m a.s.1.).

The natural potential vegetation series corresponds to Rhamno lycioidis-Querceto cocciferae sigmetum [42]. The pre-fire plant community was a Pinus halepensis Mill. forest accompanied by scrub species such as Quercus coccifera L. (kermes oak), Pistacia lentiscus L. (mastic tree), Rhamnus 
lycioides L. (black hawthorn), and Genista spartioides subsp. retamoides (Spach) Rivas Godoy \& Rivas Mart (Broom), and the steppe-grass Macrochloa tenacissima (L) Kunth (alpha grass).

\subsection{Burn Severity and Post-Fire Management}

We calculated the delta-normalized burn ratio (dNBR), relating responses of red and near infrared bands obtained from the Landsat 7 Enhanced Thematic Mapper Plus ETM+ (Level-3 from https://earthexplorer.usgs.gov) in order to draw a burn severity map for the fire perimeter [43], which was validated with field sampling (more details in [44]). In the autumn of 2012, the regional forest service carried out post-fire emergency actions (hillslope stabilization and salvage logging) to mitigate fire impacts; for example, an increase in soil quality was achieved by conforming contour-felled $\log$ debris areas and log erosion barriers area in close areas [45]. We selected a hillside comprising homogeneous pre-fire vegetation (similar cover and structure) that did not differ environmentally (northern exposure and consistent terrain, slope, orientation, elevation, and soil quality) but showing three different severity levels (unburned, low-burn severity, and high-burn severity). Thus, we defined three study subareas in the wildfire zone based on burn severity: control unburned (UB), low-burn severity (LS), and high-burn severity (HS). In addition, we also monitored a subarea defined by a salvage logging treatment carried out 6 months after the fire in the high-burn severity zone (HSSL) in order to test the appropriateness of this common post-fire practice for managing forest areas severely affected by fires. We acknowledge this sampling design can undergo spatial pseudoreplication. This fact, unavoidable in field studies, was however mitigated as much as possible by carefully selecting a quite physical homogeneous zone (see above) to place subareas with different burnt severities and post-fire treatments. Thus, it is expected that the effects of environmental gradients were minimized in relation to those coming from fire factors.

\subsection{Experimental Design and Field Sampling}

This study was conducted late in the spring of 2017 on the selected hillslope (82.24 ha) (Figure 1). Fifteen Aleppo pine trees per subarea (living pine trees in UB and LS, but dead charred snags in HS and HSSL) were randomly selected, and coordinates were recorded with a Monterra GPS receiver (Garmin International, Inc., Olathe, KS, USA).

We set circular plots whose center was a pine tree, with each plot's size equal to the soil-orthogonal projection of the pine tree canopy. We sampled plots with different sizes (not overlapping) as an individual-based area of influence (the crown of a pine tree) to determine its ecological facilitation, similarly to the "zone-of-influence for ecological facilitation" defined in [46], since competitive interactions were significant at young stages $[30,31]$.

We related the plot radius to the canopy projection for the live pine tree canopies in the UB and LS subareas and obtained a regression model for the 30-centimetre aboveground trunk diameter (PLOT radius $=\mathrm{D}_{30}$ base $\times 17.73 ; R^{2}=91.85 \% ; n=30$ ). This model allowed the plot size to be defined in the HS and HSSL subareas, where the pine tree canopy had been totally burned or removed. In 60 circular plots, three linear transects were established from the center to the edge (one oriented to the maximum slope and then $120^{\circ}$ from one to another, to prevent bias due to orientation).

The vegetation structure, species composition, and total plant cover were evaluated by recording the coverage and plant abundance by a nested sampling technique and a line intercept method because it was simple, unbiased, low-cost, and suitable for our study area [47]. Three samples were performed in each plot: (a) a plant survey by recording the species intersecting the line on a perpendicular plane according to the line transect method [48]; (b) a floristic inventory and coverages of all the species in the entire plot, the latter being visually estimated and agreed on by two expert observers following the Braun-Blanquet approach modified by [49]; and (c) pine sapling density and productivity by counting individuals and recording their height in a square subplot $\left(1 \mathrm{~m}^{2}\right)$ located in the middle of each linear transect. The nomenclature of plant species, life-form composition, and seed dispersal types were classified according to $[50,51]$. 


\subsection{Post-Fire Plant Community}

\subsubsection{Plant Diversity}

From the plant survey recorded in the line transects, $\alpha$-diversity was characterized by calculating three indices. We took floristic richness and heterogeneity, including the measure of species abundance (Shannon Index; [52]) and dominance (Simpson index; [53]). The floristic richness (S, number of species) was calculated as the number of plant species recorded on the sampling lines in each plot, plus those that did not intercept transects but were detected by the floristic inventory in the entire plot. Shannon Index ( $H^{\prime}$, adimensional) was measured as the relative abundance (interception length, in $\mathrm{cm}$ ) of the different species, including those in the plot which did not intercept lines, for which the minimum interception value (i.e., $1 \mathrm{~cm}$ ) was assigned in the calculations. The Simpson Index ( $D$, adimensional) evaluated the probability that two individuals chosen randomly would belong to the same species.

Similarly to $[8,9]$, we also characterized the function related to soil protection by calculating three variables based on their presence across the total transect length, thus expressed as \%: (a) plant coverage (PLANTcover) as the sum of all the species line interceptions, which could exceed $100 \%$ due to plants overlapping; (b) the total bare soil (BAREsoil) as the sum of the uncovered soil length along each linear transect; and (c) the surface organic matter (LITTER) as the sum of the litter duff and woody debris covering soil, excluding plant cover.

\subsubsection{Fire-Adapted Traits and Life Forms}

We classified the species according to their fire-adapted trait following the plant trait database for Mediterranean Basin species (BROT) [54]: non fire-adapted (R-S-), obligate seeder (R-S+), obligate resprouter $(\mathrm{R}+\mathrm{S}-)$, and facultative seeder $(\mathrm{R}+\mathrm{S}+)$. In each plot, we estimated the fire-adapted trait value (TRAIT) as the percentage of these fire-adapted traits in the community by grouping and averaging the visually estimated species coverages of each trait type.

The life form composition was obtained by classifying plant species into categories: trees (TREE), shrubs (SHRUB), dwarf shrubs (DWARF-S), perennial herbs (P-HERB), and annual herbs (A-HERB). The life form value (LIFE-FORM) was calculated as the ratio (\%) of the total averaged cover for each form divided by the total recorded plant cover.

According to the seed dispersal mechanism of species, we calculated the contribution of species classified as having a zoochory (ZOOC) primary dispersal strategy to the total number of species in the plot (S) in order to assess the participation of the perch effect in the post-fire regeneration. The perch effect is defined as the process in which trees are used as perches by frugivorous birds, enhancing the recruitment of fleshy-fruited plants below the trees [55].

\subsubsection{Pine Recruitment}

In order to characterize Aleppo pine recruitment, we counted and recorded all the pine saplings inside the three square subplots $\left(1 \times 1 \mathrm{~m}, 1 \mathrm{~m}^{2}\right)$ in each plot. Early pine recruitment was characterized as the mean pine sapling density five years after the fire (RECRUIT, pine saplings ha ${ }^{-2}$ ). The average and maximum heights of pine saplings (HEIGHTaver and HEIGHTmax, respectively, $\mathrm{cm}$ ) were calculated as an indirect biomass estimation.

\subsection{Statistical Analyses}

Generalized linear mixed models (GLMMs) were used to assess the effects of the selected factors (burn severity and salvage logging) and the random effects (plot size) on the response variables $\left(\mathrm{S}, \mathrm{H}^{\prime}, \mathrm{D}\right.$, PLANTcover, BAREsoil, LITTER, RECRUIT, HEIGHTaver, and HEIGHTmax). Complementarily, we carried out an analysis of variance (ANOVA) to check the significant differences related to severity or the post-fire treatment in HS independently, since the treatments were aggregated rather than placed between interleaved treatments. We carried out these analyses considering that the four selected areas 
did not differ environmentally in slope, orientation, elevation, soil quality, and structure, as well as other physical and lithological features that could bias the results.

To test the normality and homoscedasticity assumptions, the original data were transformed as required, but the tables and figures show untransformed values, including the mean and standard error $( \pm S E)$. The statistical analysis was tested for significant differences $(p<0.05)$ by a one-way analysis of variance (ANOVA). F-value and Durbin-Watson statistics were used to test the residuals and to determine if there was any significant correlation based on the order in which they occurred in the data file. We used the Tukey honest significant difference (HSD) for the post hoc comparisons in order to create confidence intervals for all the factor level means. A principal component analysis (PCA) was carried out on the studied variables to explain their variance-covariance structure through linear combinations and dimension reduction to the main components. We included the squared cosine values to select the representation quality of a variable on an axis during rotation in order to indicate a high value and proper representation quality. All analyses were run with RStudio [56] and XLSTAT [57].

\section{Results}

Regarding $\alpha$-diversity and coverage (Table 1 ), fire or post-fire treatments did not induce any significant differences in the species richness $(S)$ values. Shannon Index $\left(H^{\prime}\right)$ showed higher values in the high-burn severity stands, regardless of post-fire treatment. Simpson Index $(D)$ had higher values in LS and HSSL than in UB and HS. Only high-burn severity induced a major shift in the community LIFE-FORM composition: the UB and LS vegetations were dominated by TREE, A-HERB, and SHRUB (in this order) (Figure 2). In contrast, high-burn severity considerably reduced TREE cover and increased A-HERB, with A-HERB becoming the predominant form. The highest DWARF-S value was found in HSSL. The plant families dominating the UB community cover were Pinaceae, Gramineae, and Fagaceae (38.59\%, 47.87\%, and 20.33\% of total cover, respectively). In HS and HSSL, Gramineae (58.67\% and $22.07 \%$ of total cover, respectively) and Cistaceae $(25.33 \%$ and $11.73 \%$ of total cover, respectively) dominated. In LS, ground forest species were eliminated, while obligate seeders clearly predominated in Hs and HSSL. In addition, no significant difference in the relative abundance of zoochores species (ZOOC) was related to either burn severity (ranging from $16.25 \% \pm 9.39 \%$ in UB to $15.00 \% \pm 6.60 \%$ in HS) or salvage logging $(17.08 \% \pm 11.92 \%$ in HSSL).

Table 1. Analysis of variance (one-way ANOVA) of the recorded variables used to characterize $\alpha$-diversity $\left(S, H^{\prime}, D\right)$ and soil protection (PLANTcover, BAREsoil, LITTER,). Different lowercase letters in each column indicate significant differences between the means of groups (Tukey honest significant difference (HSD), $p<0.05$ ). Significant values are highlighted in bold.

\begin{tabular}{ccccccc}
\hline & $S$ & $H^{\prime}$ & $\boldsymbol{D}$ & PLANTcover & LITTER & BAREsoil \\
\hline UB & $20.3 \pm 1.9^{\mathrm{a}}$ & $0.952 \pm 0.049^{\mathrm{a}}$ & $0.738 \pm 0.021^{\mathrm{a}}$ & $133.86 \pm 9.91^{\mathrm{a}}$ & $31.10 \pm 4.32^{\mathrm{a}}$ & $16.02^{\mathrm{a}} \pm 4.47^{\mathrm{a}}$ \\
\hline LS & $24.7 \pm 2.3^{\mathrm{a}}$ & $0.872 \pm 0.046^{\mathrm{a}}$ & $0.921 \pm 0.011^{\mathrm{c}}$ & $149.52 \pm 8.54^{\mathrm{a}}$ & $29.53 \pm 7.29^{\mathrm{a}}$ & $28.86 \pm 3.08^{\mathrm{ab}}$ \\
\hline HS & $23.6 \pm 2.0^{\mathrm{a}}$ & $1.122 \pm 0.041^{\mathrm{b}}$ & $0.736 \pm 0.021^{\mathrm{a}}$ & $119.86 \pm 6.67^{\mathrm{b}}$ & $12.79 \pm 1.83^{\mathrm{b}}$ & $19.55 \pm 3.65^{\mathrm{ab}}$ \\
\hline HSSL & $25.0 \pm 2.3^{\mathrm{a}}$ & $1.170 \pm 0.048^{\mathrm{b}}$ & $0.809 \pm 0.010^{\mathrm{b}}$ & $93.90 \pm 6.89^{\mathrm{c}}$ & $8.67 \pm 0.98^{\mathrm{c}}$ & $30.25 \pm 2.64^{\mathrm{b}}$ \\
\hline $\begin{array}{c}p \text {-value } \\
F \text {-value }\end{array}$ & 0.340 & $\mathbf{0 . 0 4 8}$ & $\mathbf{0 . 0 0 0}$ & $\mathbf{0 . 0 0 0}$ & $\mathbf{0 . 0 0 1}$ & $\mathbf{6 . 0 1 0}$ \\
\hline
\end{tabular}

Pinus halepensis recruitment (RECRUIT) was significantly greater in HS $(110,444 \pm 9767$ pine saplings $\left.\mathrm{ha}^{-1}\right)$ than in UB or LS $\left(444 \pm 311\right.$ and $34,667 \pm 5645$ pine saplings ha ${ }^{-1}$, respectively), but post-fire management reduced it in HSSL $\left(30,889 \pm 9702\right.$ pine saplings ha $\left.{ }^{-1}\right)$. We found no significant differences in HEIGHTaver among the four zones, but HEIGHTmax indicated that pine saplings were taller in HS $(42.76 \pm 3.29 \mathrm{~cm})$ than in HSSL and LS $(29.49 \pm 2.30$ and $26.74 \pm 3.15 \mathrm{~cm}$, respectively). The plant community structure was negatively affected by increased burn severity, comparing the three levels. PLANTcover and LITTER were significantly reduced by high-burn severity, 
especially when logging was carried out after fire (HSSL), which led to the highest BAREsoil values in this stand (Table 1). Regarding adaptive plant trait strategies to fire (Figure 3), the presence of R-Sspecies was generally scarce in the study area and was recorded only in the UB stand. Fire drastically reduced the presence of the $\mathrm{R}+\mathrm{S}+$ species, especially when it occurred at high severity. Conversely, the relative cover of the R-S+ species was favored by fire severity. The relative abundance of resprouters $(\mathrm{R}+\mathrm{S}-)$ did not show any clear pattern, but resprouters were notably present in all of the scenarios.

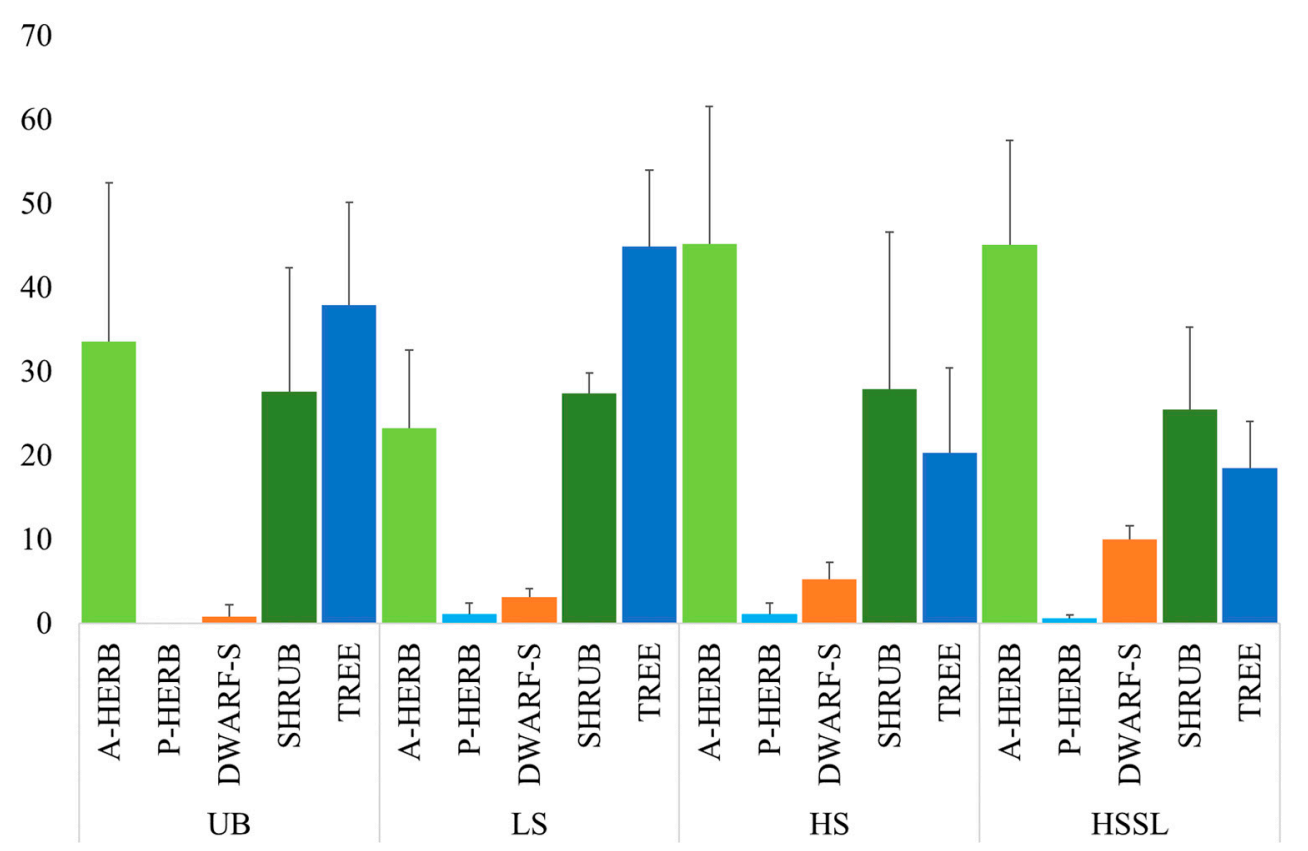

Figure 2. Mean relative values (including standard error) of the life form composition (LIFE-FORM, \%) in the studied areas (UB: unburned; LS: low-burn severity; HS: high-burn severity; HSSL: salvage logging in high-burn severity) according to the defined categories: trees (TREE), shrubs (SHRUB), dwarf shrubs (DWARF-S), perennial herbs (P-HERB), and annual herbs (A-HERB).

A PCA was carried out on the studied variables to explain their variance-covariance structure through linear combinations and dimension reduction to the main components. The PCA reduced the dimension to a five-component solution (eigenvalues $>1$ ), but we chose a simplified model for a biplot component (axes PCA1 and PCA2; Figure 4). The first component accounted for $26.2 \%$ of variability, while the second explained $15.9 \%$. Plant community responses, mainly the pine recruitment and plant diversity patterns response to burn severity and salvage logging, clearly clustered along the PCA1 axis, whereas the post-fire vegetation cover related to adaptive traits was linked with the PCA2 axis. In the PCA, we found that PCA1 related the pine recruitment and plant diversity patterns to burn severity and post-fire management. The PCA1 axis included RECRUIT, HEIGHTaver, and HEIGHTmax (0.497, 0.545 , and 0.580 , respectively). The PCA2 axis showed an influence of post-fire adaptive traits. In PCA2, the squared cosine values highlighted the variables $R+S-(0.493)$ and $R-S+(0.671)$, which indicates that obligate seeders predominated in high-burn severity areas. 


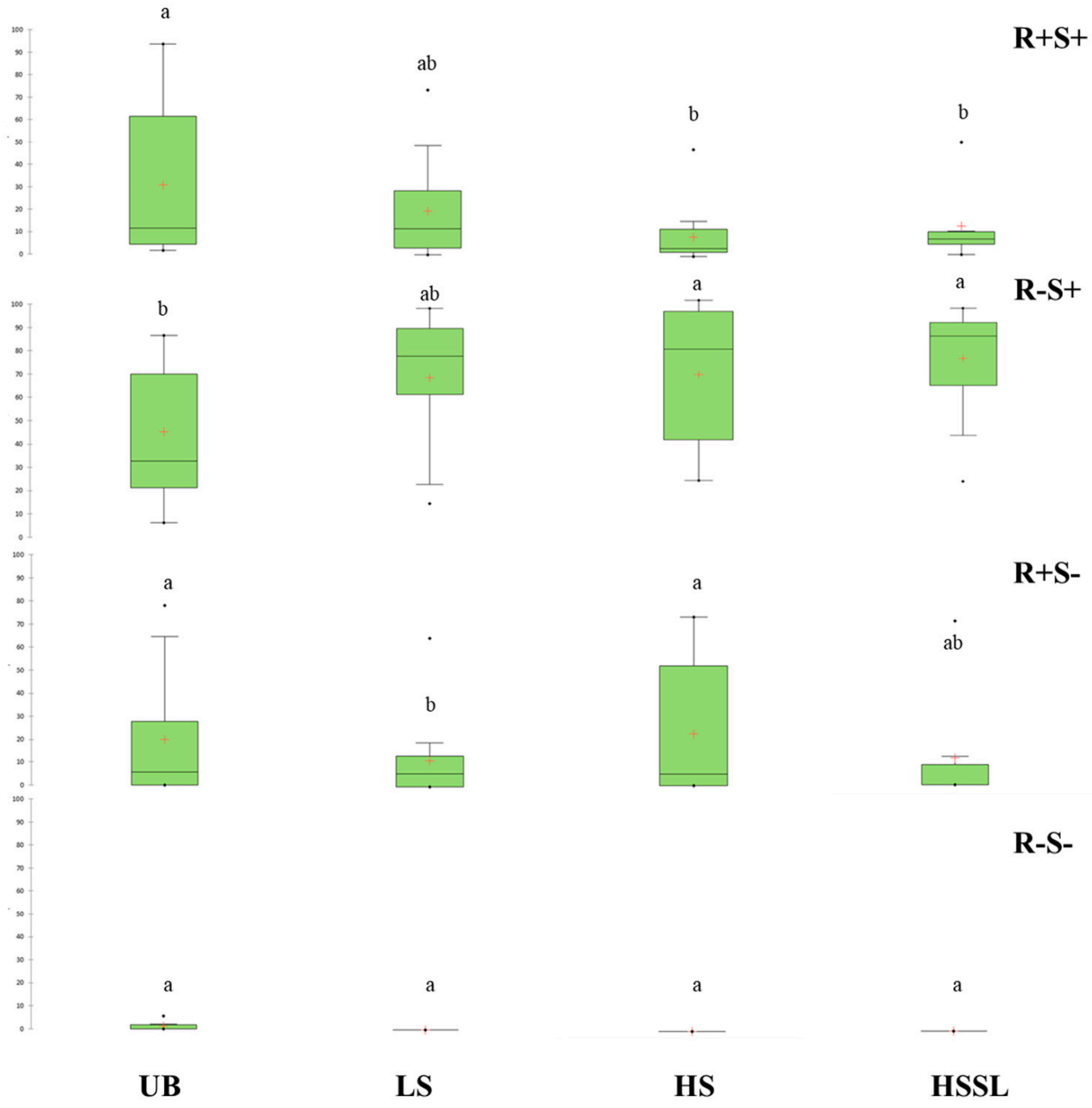

Figure 3. Box and whiskers ANOVA (limits of boxplots represent upper and lower quartiles, the central line is the median, asterisks are outliers, and whiskers indicate the highest and lowest observations) showing averaged coverages of visually estimated species (red cross) recorded according to post-fire trait adaptive strategies (TRAIT, \%)): non-adaptive post-fire traits (R-S-), obligate seeder (R-S+), obligate resprouters (R+S-), and facultative seeder $(\mathrm{R}+\mathrm{S}+)$. The plots sampled five years after the fire were set in unburned natural Aleppo pine stands (UB), low-burn severity (LS), high-burn severity unmanaged (HS), and high-burn severity after post-fire salvage logging (HSSL). Different lowercase letters in each column indicate significant differences between the means of groups (Tukey honest significant difference (HSD), $p<0.05$ ). 


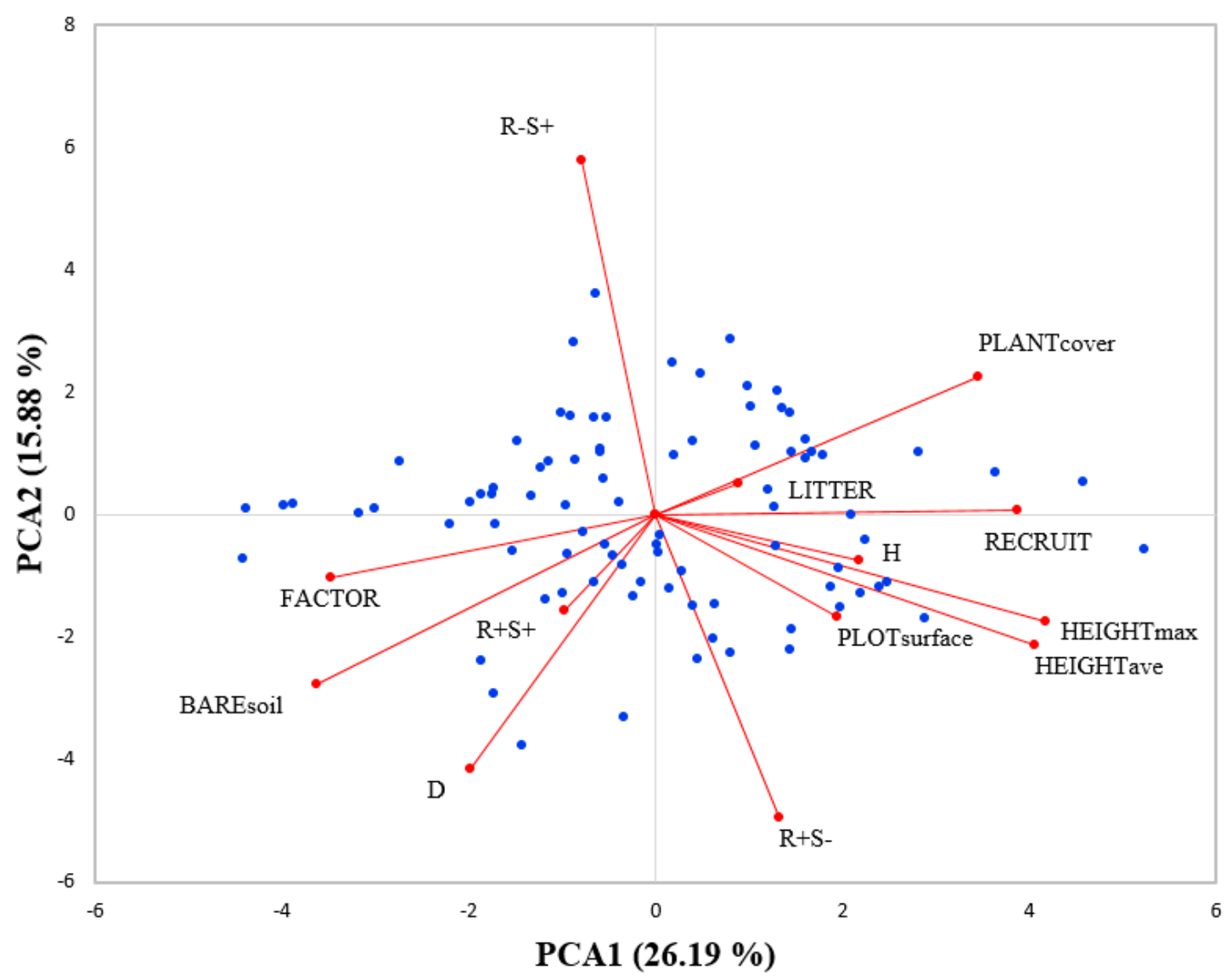

Figure 4. The principal component analysis (PCA) biplot diagram for the studied variables. FACTOR: burn severity and post-fire management; RECRUIT: pine sapling density; HEIGHTaver: average pine seeding height; HEIGHTmax: maximum pine seeding height; PLOTsurface: surface of the sampling plot; $\mathrm{R}+\mathrm{S}$-: relative cover of obligate resprouters; $\mathrm{R}-\mathrm{S}+$ : relative cover of obligate seeders; $\mathrm{R}+\mathrm{S}+$ : relative cover of facultative seeders; $D$ : Simpson's Dominance Index; $H^{\prime}$ : Shannon's Diversity Index; BAREsoil: percentage of uncovered soil; PLANTcover: percentage of plant coverage; LITTER: percentage of surface organic matter (duff and woody debris). Blue dots represent standardized values of variables recorded after a wildfire event. PCA1: Pine recruitment and plant diversity patterns response to burn severity and post-fire management; PCA2: Post-fire adaptive traits.

\section{Discussion}

Salvage logging after forest disturbances, particularly wildfires, is a controversial but commonplace practice that remains quite poorly studied in Mediterranean countries [58]. In semiarid areas, the interaction between treatment and climate could include non-additive effects between natural disturbance and logging, which could lead to the exceeding of the recovery threshold [59]. We obtained unbiased results that explained the random effects, but the aggregated effect of salvage logging on high burn severity reduced the strength of the conclusions we obtained. We admit that our sampling design shows pseudoreplication, which is often unavoidable in field studies. However, the careful selection of a quite homogeneous zone for the study should minimize the effects of environmental gradients and thus confers validity to our results.

We found that the effect of snags on ecological facilitation was negligible in terms of plant diversity and community recovery patterns. Nevertheless, salvage logging had a negative effect on pine seedling density and growth of the recruitment. According to [46], in stressed communities, such as the current semiarid area, facilitation can affect biomass-density relations, but only in intermediate plant densities. 
We found no differences in the relative abundance of zoochores, despite salvage logging possibly benefiting some bird species [60] and the activity of some of these species qualitatively and quantitatively interacting as seed dispersers by shaping the vegetation distribution patterns in mature forests in the southeastern Iberian Peninsula [61]. So, our hypothesis that older snags increase ecological facilitation and promote vegetation recovery by increasing the recruitment of fleshy-fruited species [55,62] was not corroborated. This functional group may generally be poorly represented in our system, unlike other Iberian ecosystems in this semiarid southeastern area (e.g., [63,64]). Therefore, detailed information about functional groups in the ecosystem is important when making post-fire management decisions.

In the mid-term, we corroborated that high-burn severity promotes alpha diversity. $D$ showed lower biodiversity in LS or HSSL because pine tree (adults and/or saplings) predominated, which could be considered an indication of moderate disturbance levels according to ecological theories [65], similar to other coniferous forests in the western USA [66]. The other diversity indices indicated that burning had no effects (i.e., floristic richness showed no significant differences in the sampled area or enhanced biodiversity, and $H^{\prime}$ was higher in the areas burned with high severity independently of the post-fire treatment, similar to other Mediterranean habitats) [67]. The composition of adaptive traits in the study area indicated the importance of fire, as it forces species selection in these semiarid Mediterranean ecosystems [68], as R-S- almost did not appear. Obligate seeders appeared to represent an efficient strategy for facing high-severity fires in these ecosystems [54] (e.g., heliophiles, xerophiles, plants with seed banks, frugality, invasive nature, etc.). Pine, even in salvage logged sites, is seen as a pyrophyte species in these semiarid systems, as it positively responds to severe fires [27], which leads to greater regeneration in high-burn severity areas.

Resprouters displayed no clear pattern in relation to fire severity in our study area, but are present in all scenarios, which suggests that they have an efficient strategy that may go beyond adaptation only to fire (i.e., water and/or edaphic stress) [69]. R-S- are barely represented in the ecosystem, which means that distributions are profoundly modelled by fire regime, although the pattern is widely variable in some areas and influenced by local abiotic factors, such as topographic or microclimatic conditions [70].

When we compared the high-burn severity subareas, both unmanaged and after salvage logging, we assumed that the absence of biomass removal would facilitate survival in a microclimate (under pine tree canopy) and would mitigate the effects of the soil losses documented in other studies conducted in the Iberian Peninsula [71-74]. Obviously, burn severity impacted the plant community, with a greater reduction in biomass with higher burn severity, and vegetation recovery depended on the time after fire [75], although it apparently adapted to the succession pattern model of the Egler "initial floristic composition" [76]. The effect on the variables describing soil protection (PLANTcover, BAREsoil, and LITTER) highlighted that LS suffered weaker effects, and had recovered before 5 years had elapsed after fire, as reinforced by the results related to LIFE-FORM and the main families found.

High fire severity also eliminates trees and allows dwarf shrubs and herbs, mainly annuals, to predominate in pioneering stages along with many Cistaceae and Poaceae. Cistaceae plants proliferated from the soil seed bank, and Poaceae invaded burned areas via the dispersal of seed from adjacent spots. In this way, we found that salvage logging increased the negative impact of fire on soil cover, thus reducing soil protection-related functions. Additionally, in the wood-logged area, the obligate seeders predominated and the presence of DWARF-S increased, mainly due to massive Cistaceae regeneration from the soil seed bank. The lower resprouters presence could delay natural ecosystem regeneration and resilience, especially in these semiarid areas with little primary productivity [77]. Indeed, Cistaceae shrubs have been revealed as dominant competitors against $P$. halepensis saplings in early post-fire stages of similar ecosystems [78].

Salvage logging also amplified the negative impacts found in high-burn areas related to early pine recruitment, characterized here as pine seedling density and the qualitative assessment of sapling biomass (HEIGHTaver and HEIGHTmax), which involves a certain facilitative effect for wood debris, as we detected greater stress (and less growth) for pine recruitment in areas where wood debris was present. However, considering that some potentially influential variables, such as soil nutrients or 
biological soil properties [45], were not monitored, this could help to explain the above observations. Although the post-fire felling effect depends on the treatment intensity and management practices related to salvage logging $[70,79,80]$, other more conservative treatments improve pine recruitment and growth [81]. Other studies performed in nearby areas concluded that this practice could jeopardize natural pine tree regeneration in Mediterranean P. halepensis forests [30,31]. When carrying out salvage logging in areas with high risk of loss of ecosystem functions, the proposed practices should be deeply studied before execution, including considerations of other important variables in the monitoring process, such as land form or the pre-fire aerial canopy seed bank [82], in order to prevent the possibility of further ecosystem damage.

\section{Conclusions}

As a general conclusion, we found affected diversity patterns and vegetation recovery in burned areas. Our research was centered on studying living trees and snags in order to describe differences in ecosystem damage related to the burn severity. We corroborated the negative effects, similarly to other studies, of including a post-fire treatment as restoration tool. Due to the low pine tree density, we focused on the effects of snag retention on the immediate environment, since random sampling was diluting the possible effects of this factor.

Low-burn severity depletes the system's plant diversity, but maintains other basic functions (e.g., soil protection). High-burn severity strongly affects the community structure (cover, litter, changes in taxonomic composition and biotypes, loss of predominating trees, etc.) and leaves a considerable amount of soil unprotected. In addition, salvage logging amplifies the negative effects related to high-burn severity, such as impacts on pine seedling density and pine sapling growth. This could prolong the time needed to recover ecological functions despite a disturbance occurring in a resilient habitat $[9,11]$. These findings supplement the results of other studies that have associated greater environmental damage with high-burn severity, with examples of soil loss [83] and impacts on plant abundance/diversity and soil productivity [84].

The salvage logging that has been usually used as a post-fire restoration tool promotes negative effects on Aleppo pine forest functions, reducing the natural recovery of vegetation and changing the post-fire composition and structure of the plant community, although will not be significant for the regeneration of the general plant community (total plant and litter cover). This negative effect increases the system's vulnerability and extends the time required for the pre-fire functions and ecosystem services to return.

We recommend increasing fire prevention to reduce fire risk and improve success in firefighting in order to reduce the amount of burned surface and lessen burn severity [85], or at least to attempt to reduce high-burn severity zones to prevent flora homogenization on the regional scale in semiarid areas with changing fire regimes $[86,87]$.

In the event of the occurrence of a wildfire in this habitat type, we suggest that the post-fire management should plan to avoid salvage logging or should at least retain enough older snags to prevent ecosystem damage. As a useful tool for ecosystem restoration, this strategy favors pine regeneration and promotes landscape heterogeneity, interspersing felled and uncut areas to promote diversity. However, changes in soil properties could be determining future natural recovery, which should be considered in future research. This procedure will provide a suitable habitat for more species and habitat type by increasing community resilience to future wildfires (sensu [88]). It will also provide synergies with other functions and service ecosystems, mainly in special protection areas [89].

Author Contributions: Conceptualization: D.M., P.F., J.D.L.H., and M.E.L.-B.; Methodology: D.M., P.F., and J.S.; Data collection: D.M., J.S., P.F., P.A.P.-Á., and J.G.-R.; Formal analysis and data curation, D.M., P.F., and M.E.L.-B.; Writing-review and editing: D.M., P.F., and J.D.L.H.; Project administration and funding acquisition: D.M., J.D.L.H., and P.F. All authors have read and agreed to the published version of the manuscript.

Funding: Javier Sagra was supported by a doctoral fellowship from the Internal Research Plan of the University of Castilla-La Mancha, co-financed by the European Social Fund (PREDUCLM15/32). This study was also 
funded by the Spanish Institute for Agricultural and Food Research and Technology (INIA) to award National Research Projects GEPRIF (RTA2014-00011-C06) and VIS4FIRE (RTA2017-00042-C05-00). The authors also wish to acknowledge the funds from the University of Castilla-La Mancha to the Forest Ecology (FORECO) and Plant Conservation (COFA) Research Groups. Pedro Antonio Plaza Álvarez was supported by a predoctoral fellowship from the Spanish Ministry of Education, Culture and Sport (FPU16/03296). J. González-Romero holds a scholarship (Sbply/16/180501/000109) from the Regional 721 Government of Castilla-La Mancha/European Social Fund (ESF, EU).

Acknowledgments: The authors wish to thank the Castilla-La Mancha Regional Forest Service and GEACAM for the information and support provided, and also Helen Warburton for her professional English editing and suggestions.

Conflicts of Interest: The authors declare no conflict of interest.

\section{References}

1. Pausas, J.G.; Keeley, J.E. Wildfires as an ecosystem service. Front. Ecol. Environ. 2019, 17, 289-295. [CrossRef]

2. Pausas, J.G.; Fernández-Muñoz, S. Fire regime changes in the Western Mediterranean Basin: From fuel-limited to drought-driven fire regime. Clim. Chang. 2012, 110, 215-226. [CrossRef]

3. Dale, V.H.; Joyce, L.A.; McNulty, S.; Neilson, R.P.; Ayres, M.P.; Flannigan, M.D.; Wotton, B.M. Climate Change and Forest Disturbances. Bioscience 2001, 51, 723-734. [CrossRef]

4. Certini, G. Fire as a Soil-Forming Factor. AMBIO 2014, 43, 191-195. [CrossRef]

5. Doblas-Miranda, E.; Alonso, R.; Arnan, X.; Bermejo, V.; Brotons, L.; de las Heras, J.; Estiarte, M.; Hódar, J.A.; Llorens, P.; Lloret, F.; et al. A review of the combination among global change factors in forests, shrublands and pastures of the Mediterranean. Glob. Planet. Chang. 2017, 148, 42-54. [CrossRef]

6. Ibáñez, I.; Acharya, K.; Juno, E.; Karounos, C.; Lee, B.R.; McCollum, C.; Schaffer-Morrison, S.; Tourville, J. Forest resilience under global environmental change: Do we have the information we need? A systematic review. PLoS ONE 2019, 14, e0222207. [CrossRef] [PubMed]

7. Newton, A.C.; Cantarello, E. Restoration of forest resilience: An achievable goal? New For. 2015, 46, 645-668. [CrossRef]

8. Keeley, J.E. Fire intensity, fire severity and burn severity: A brief review and suggested usage. Int. J. Wildland Fire 2009, 18, 116-126. [CrossRef]

9. López-Poma, R.; Bautista, S. Plant regeneration functional groups modulate the response to fire of soil enzyme activities in a Mediterranean shrubland. Soil Biol. Biochem. 2014, 79, 5-13. [CrossRef]

10. González-De Vega, S.; de las Heras, J.; Moya, D. Post-Fire Regeneration and Diversity Response to Burn Severity in Pinus halepensis Mill. forests. Forests 2018, 9, 299. [CrossRef]

11. Eugenio, M.; Verkaik, I.; Lloret, F.; Espelta, J. Recruitment and growth decline in Pinus halepensis populations after recurrent wildfires in Catalonia (NE Iberian Peninsula). For. Ecol. Manag. 2006, 231, 47-54.

12. González-De Vega, S.; De las Heras, J.; Moya, D. Resilience of Mediterranean terrestrial ecosystems and fire severity in semiarid areas: Responses of Aleppo pine forests in the short, mid and long term. Sci. Total Environ. 2016, 573, 1171-1177. [CrossRef] [PubMed]

13. Viana-Soto, A.; Aguado, I.; Martínez, S. Assessment of Post-Fire Vegetation Recovery Using Fire Severity and Geographical Data in the Mediterranean Region (Spain). Environments 2017, 4, 90. [CrossRef]

14. Brown, J.K.; Smith, J.K. Wildland fire in ecosystems: Effects of fire on flora. In General Technical Reports Rocky Mountin Research Station; U.S. Department of Agriculture, Forest Service, Rocky Mountain Research Station: Ogden, UT, USA, 2000; Volume 42, 257p.

15. Santin, C.; Doerr, S.H. Fire effects on soils: The human dimension. Philos. Trans. R. Soc. Biol. Sci. 2016, 371, 20150171. [CrossRef]

16. Smith, J.K. Wildland fire in ecosystems: Effects of fire on fauna. In General Technical Reports Rocky Mountin Research Station; U.S. Department of Agriculture, Forest Service, Rocky Mountain Research Station: Ogden, UT, USA, 2000; Volume 42, 83p.

17. Lee, C.; Schlemme, C.; Murray, J.; Unsworth, R. The cost of climate change: Ecosystem services and wildland fires. Ecol. Econ. 2015, 116, 261-269. [CrossRef]

18. Kelly, L.T.; Brotons, L. Using fire to promote biodiversity. Science 2017, 355, 8-9. [CrossRef] 
19. Serrano-Ortiz, P.; Marañón-Jiménez, S.; Reverter, B.R.; Sánchez-Cañete, E.P.; Castro, J.; Zamora, R.; Kowalski, A.S. Post-fire salvage logging reduces carbon sequestration in Mediterranean coniferous forest. For. Ecol. Manag. 2011, 262, 2287-2296. [CrossRef]

20. Lucas-Borja, M.E.; González-Romero, J.; Plaza-Álvarez, P.A.; Sagra, J.; Gómez, M.E.; Moya, D.; Cerdà, A.; de las Heras, J. The impact of straw mulching and salvage logging on post-fire runoff and soil erosion generation under Mediterranean climate conditions. Sci. Total Environ. 2019, 654, 441-451. [CrossRef]

21. Tapias, R.; Gil, L.; Fuentes-Utrilla, P.; Pardos, J.A. Canopy seed banks in Mediterranean pines of southeastern Spain: A comparison between Pinus halepensis Mill.; P. pinaster Ait.; P. nigra Arn. and P. pinea L. J. Ecol. 2001, 89, 629-638. [CrossRef]

22. Daskalakou, E.; Costas, A.T. Aleppo pine (Pinus halepensis) Postfire Regeneration: The Role of Canopy and Soil Seed Banks. Int. J. Wildland Fire 1996, 6, 59-66. [CrossRef]

23. Goubitz, S.; Nathan, R.; Roitemberg, R.; Shmida, A.; Ne'eman, G. Canopy seed bank structure in relation to: Fire, tree size and density. Plant. Ecol. 2004, 173, 191-201. [CrossRef]

24. Moya, D.; De las Heras, J.; López-Serrano, F.R.; Leone, V. Optimal intensity and age of management in young Aleppo pine stands for post-fire resilience. For. Ecol. Manag. 2008, 255, 3270-3280. [CrossRef]

25. Saracino, A.; Bellino, A.; Allevato, E.; Mingo, A.; Conti, S.; Rossi, S.; Bonanomi, G.; Carputo, D.; Mazzoleni, S. Repeated Stand-Replacing Crown Fires Affect Seed Morphology and Germination in Aleppo pine. Front. Plant Sci. 2017, 8, 1160. [CrossRef] [PubMed]

26. Sarris, D.; Christodoulakis, D.; Körner, C. Impact of recent climatic change on growth of low elevation eastern Mediterranean forest trees. Clim. Chang. 2011, 106, 203-223. [CrossRef]

27. Nathan, R.; Ne'eman, G. Serotiny seed dispersal and seed predation in Pinus halepensis. In Ecology, Biogeography and Management of Pinus halepensis and P. brutia Forest Ecosystems in the Mediterranean Basin; Ne'eman, G., Trabaud, L., Eds.; Backhuys Publishers: Leiden, The Netherlands, 2000; pp. 105-118.

28. Hernandez-Serrano, A.; Verdu, M.; Gonzalez-Martinez, S.C.; Pausas, J.G. Fire structures pine Serotiny at different scales. Am. J. Bot. 2013, 100, 2349-2356. [CrossRef]

29. Alfaro-Sanchez, R.; Camarero, J.J.; Lopez-Serrano, F.R.; Sanchez-Salguero, R.; Moya, D.; de las Heras, J. Positive coupling between growth and reproduction in young post-fire Aleppo pines depends on climate and site conditions. Int. J. Wildland Fire 2015, 24, 507-517. [CrossRef]

30. Martínez-Sánchez, J.J.; Ferrandis, P.; de las Heras, J.; Herranz, J.M. Effect of burnt wood removal on the natural regeneration of Pinus halepensis after fire in a pine forest in Tus valley (SE Spain). For. Ecol. Manag. 1999, 123, 1-10. [CrossRef]

31. Moya, D.; de las Heras, J.; López-Serrano, F.R.; Ferrandis, P. Post-Fire Seedling Recruitment and Morpho-Ecophysiological Responses to Induced Drought and Salvage Logging in Pinus halepensis Mill. stands. Forests 2015, 6, 1858-1877. [CrossRef]

32. Castro, J.; Allen, C.D.; Molina-Morales, M.; Marañón-Jiménez, S.; Sánchez-Miranda, A.; Zamora, R. Salvage Logging Versus the Use of Burnt Wood as a Nurse Object to Promote Post-Fire Tree Seedling Establishment. Restor. Ecol. 2011, 19, 537-544. [CrossRef]

33. Marañón-Jiménez, S.; Castro, J.; Kowalski, A.S.; Serrano-Ortiz, P.; Reverter, B.R.; Sánchez-Cañete, E.P.; Zamora, R. Post-fire soil respiration in relation to burnt wood management in a Mediterranean mountain ecosystem. For. Ecol. Manag. 2011, 261, 1436-1447. [CrossRef]

34. Puig-Gironès, R.; Imbeau, L.; Clavero, M.; Rost, J.; Pons, P. Does post-fire salvage logging affect foraging activity by rodents? Eur. J. For. Res. 2020, 139, 777-790. [CrossRef]

35. Marcolin, E.; Marzano, R.; Vitali, A.; Garbarino, M.; Lingua, E. Post-Fire Management Impact on Natural Forest Regeneration through Altered Microsite Conditions. Forests 2019, 10, 1014. [CrossRef]

36. Taboada, A.; Fernández-García, V.; Marcos, E.; Calvo, L. Interactions between large high-severity fires and salvage logging on a short return interval reduce the regrowth of fire-prone serotinous forests. For. Ecol. Manag. 2018, 414, 54-63. [CrossRef]

37. DeRose, R.J.; Long, J.N. Resistance and Resilience: A Conceptual Framework for Silviculture. For. Sci. 2014, 60, 1205-1212. [CrossRef]

38. Spanish Geographic Institute. Centro de Descargas del Centro Nacional de Información Geográfica, Spain. 2020. Available online: http://centrodedescargas.cnig.es/CentroDescargas/index.jsp (accessed on 16 December 2020).

39. Kottek, M.; Grieser, J.; Beck, C.; Rudolf, B.; Rubel, F. World Map of the Köppen-Geiger climate classification updated. Meteorol. Z. 2006, 15, 259-263. [CrossRef] 
40. García-Morote, F.A.; Martínez-García, E.; Andrés-Abellán, M.; Caballero, E.R.; Miettinen, H.; López-Serrano, F.R. Direct seeding of Pinus halepensis Mill. for recovery of burned semi-arid forests: Implications for post-fire management for improving natural regeneration. Forests 2017, 8, 353. [CrossRef]

41. Soil Survey Staff. Keys to Soil Taxonomy, 12th ed.; USDA-Natural Resources Conservation Service: Washington, DC, USA, 2014.

42. Rivas-Martínez, S. Memoria del Mapa de Series de Vegetación de España 1: 400.000; ICONA, Ministerio de Agricultura, Pesca y Alimentación: Madrid, Spain, 1987; 268p.

43. Miller, J.D.; Thode, A. Quantifying burn severity in a heterogeneous landscape with a relative version of the delta Normalized Burn Ratio (dNBR). Remote Sens. Environ. 2007, 109, 66-80. [CrossRef]

44. Gómez-Sánchez, E.; De las Heras, J.; Lucas-Borja, M.; Moya, D. Ajuste de metodologías para evaluar severidad de quemado en zonas semiáridas (SE peninsular): Incendio Donceles 2012. Rev. Teledet. 2017, 49, 103-113. [CrossRef]

45. Gómez-Sánchez, E.; Lucas-Borja, M.E.; Plaza-Álvarez, P.A.; González-Romero, J.; Sagra, J.; Moya, D.; de las Heras, J. Effects of post-fire hillslope stabilisation techniques on chemical, physicochemical and microbiological soil properties in mediterranean forest ecosystems. J. Environ. Manag. 2019, 246, 229-238. [CrossRef]

46. Chu, C.; Maestre, F.T.; Xiao, S.; Weiner, J.; Wang, Y.; Duan, Z.; Wang, G. Balance between facilitation and resource competition determines biomass-density relationships in plant populations. Ecol. Lett. 2008, 11, 1189-1197. [CrossRef]

47. Stohlgren, T.J.; Falkner, M.; Schell, D.L. A Modified-Whittaker nested vegetation sampling method. Plant Ecol. 1995, 117, 113-121. [CrossRef]

48. Buckland, S.T.; Borchers, D.L.; Johnston, A.; Henrys, P.A.; Marques, T.A. Line transect methods for plant surveys. Biometrics 2007, 63, 989-998. [CrossRef] [PubMed]

49. Van der Maarel, E. Transformation of cover-abundance values for appropriate numerical treatment-Alternatives to the proposals by Podani. J. Veg. Sci. 2007, 18, 767-770.

50. Tutin, T.G.; Heywood, V.H.; Burges, N.A.; Moore, D.M.; Valentine, D.H.; Walters, S.M.; Webb, D.A. Flora Europaea 1-5; Cambridge University Press: Cambridge, UK, 1964.

51. Castroviejo, S. Flora Ibérica 1-8, 10-15, 17-18, 21; Real Jardín Botánico; CSIC: Madrid, Spain, 2012.

52. Shannon, C. A mathematical theory of communication. Bell. Syst. Tech. J. 1948, 27, 379-423. [CrossRef]

53. Simpson, E.H. Measurement of diversity. Nature 1949, 163, 688. [CrossRef]

54. Paula, S.; Arianoutsou, M.; Kazanis, D.; Tavsanoglu, Ç.; Lloret, F.; Buhk, C.; Ojeda, F.; Luna, B.; Moreno, J.M.; Rodrigo, A. Fire-related traits for plant species of the Mediterranean Basin. Ecology 2009, 90, 1420. [CrossRef]

55. Pausas, J.G.; Bonet, A.; Maestre, F.T.; Climent, A. The role of the perch effect on the nucleation process in Mediterranean semi-arid oldfields. Acta Oecol. 2006, 29, 346-352. [CrossRef]

56. R Development Core Team. R: A Language and Environment for Statistical Computing; R Foundation for Statistical Computing: Vienna, Austria, 2011; Available online: http://www.R-project.org (accessed on 16 December 2020).

57. Addinsoft. XLSTAT Statistical and Data Analysis Solution; Addinsoft: New York, NY, USA, 2020; Available online: https://www.xlstat.com (accessed on 16 December 2020).

58. Thorn, S.; Bässler, C.; Brandl, R.; Burton, P.J.; Cahall, R.; Campbell, J.L.; Castro, J.; Choi, C.Y.; Cobb, T.; Donato, D.C.; et al. Impacts of salvage logging on biodiversity: A meta-analysis. J. Appl. Ecol. 2018, 55, 279-289. [CrossRef]

59. Leverkus, A.B.; Lindenmayer, D.B.; Thorn, S.; Gustafsson, L. Salvage logging in the world's forests: Interactions between natural disturbance and logging need recognition. Glob. Ecol. Biogeogr. 2018, 27, 1140-1154. [CrossRef]

60. Rost, J.; Clavero, M.; Brotons, L.; Pons, P. The effect of postfire salvage logging on bird communities in Mediterranean pine forests: The benefits for declining species. J. Appl. Ecol. 2012, 49, 644-651. [CrossRef]

61. Zapata, V.M.; Robledano, F.; Ramos, V.; Martínez-López, V. Bird-mediated seed dispersal of fleshy fruits of mediterranean shrubs in semiarid forest patches: The role of Pinus halepensis Miller trees as seed receptors. Plant Ecol. 2014, 215, 1337-1350. [CrossRef]

62. Castro, J.; Puerta-Piñero, C.; Leverkus, A.B.; Moreno-Rueda, G.; Sánchez-Miranda, A. Post-fire salvage logging alters a key plant-animal interaction for forest regeneration. Ecosphere 2012, 3, 1-12. [CrossRef]

63. García Fayos, P.; Verdú, M. Soil seed bank, factors controlling germination and establishment of a Mediterranean shrub: Pistacia lentiscus L. Acta Oecol. 1998, 19, 357-366. [CrossRef] 
64. Bonet, A. Secondary succession of semi-arid Mediterranean old-fields in south-eastern Spain: Insights for conservation and restoration of degraded lands. J. Arid Environ. 2004, 56, 213-233. [CrossRef]

65. Huston, M.A. Disturbance, productivity, and species diversity: Empiricism vs. logic in ecological theory. Ecology 2014, 95, 2382-2396. [CrossRef]

66. Strand, E.K.; Satterberg, K.L.; Hudak, A.T. Does burn severity affect plant community diversity and composition in mixed conifer forests of the United States Intermountain West one decade post fire? Fire Ecol. 2019, 15, 25. [CrossRef]

67. Schwilk, D.W.; Keeley, J.E.; Bond, W.J. The intermediate disturbance hypothesis does not explain fire and diversity pattern in fynbos. Plant Ecol. 1997, 132, 77-84. [CrossRef]

68. Keeley, J.E.; Pausas, J.G.; Rundel, P.W.; Bond, W.J.; Bradstock, R.A. Fire as an evolutionary pressure shaping plant traits. Trends Plant. Sci. 2011, 16, 406-411. [CrossRef]

69. Keeley, J.E. Fire in Mediterranean Ecosystems: Ecology, Evolution and Management; Cambridge University Press: Cambridge, UK, 2012.

70. Buhk, C.; Götzenberger, L.; Wesche, K.; Sánchez-Gómez, P.; Hensen, I. Post-fire regeneration in a Mediterranean pine forest with historically low fire frequency. Acta Oecol. 2006, 30, 288-298. [CrossRef]

71. Leverkus, A.B.; Gustafsson, L.; Lindenmayer, D.B.; Castro, J.; Rey-Benayas, J.M.; Ranius, T.; Thorn, S. Salvage logging effects on regulating ecosystem services and fuel loads. Front. Ecol. Environ. 2020, 18, 391-400. [CrossRef]

72. Martínez-Murillo, J.F.; López-Vicente, M. Effect of Salvage Logging and Check Dams on Simulated Hydrological Connectivity in a Burned Area. Land Degrad. Dev. 2018, 29, 701-712. [CrossRef]

73. Mauri, E.; Pons, P. Handbook of Good Practices in Post-Wildfire Management, 2nd ed.; Anifog Project I+D+i CGL2014-54094-R; Universitat de Girona: Girona, Spain, 2019.

74. Moya, D.; de las Heras, J.; Ferrandis, P.; Herranz, J.M.; Martínez-Sánchez, J.J. Fire resilience and forest restoration in Mediterranean fire-prone areas. Tech. Know. Transf. E-Bull. 2011, 2.

75. Clark, J.A.; Covey, K. Tree species richness and the logging of natural forests: A meta-analysis. For. Ecol. Manag. 2012, 276, 146-153. [CrossRef]

76. Georgiadis, G.V.; Georgiadis, T. Post-Fire Vegetation Succession: The Case of Aleppo Pine (Pinus halepensis Miller) Forests of Northern Achaia (Greece). Fresenius Environ. Bull. 2002, 11, 186-193.

77. Leverkus, A.B.; Lorite, J.; Navarro, F.B.; Sánchez-Cañete, E.P.; Castro, J. Post-fire salvage logging alters species composition and reduces cover, richness, and diversity in Mediterranean plant communities. J. Environ. Manag. 2014, 133, 323-331. [CrossRef]

78. Martínez-Sánchez, J.J.; Ferrandis, P.; Trabaud, L.; Galindo, R.; Franco, J.A.; Herranz, J.M. Comparative root system structure of post-fire Pinus halepensis Mill. and Cistus monspeliensis L. saplings. Plant Ecol. 2003, 168, 309-320. [CrossRef]

79. Vega, J.A.; Fernández-Filgueira, C.; Pérez-Gorostiaga, P.; Fonturbel, T. Response of maritime pine (Pinus pinaster Ait.) recruitment to fire severity and post-fire management in a coastal burned area in Galicia (NW Spain). Plant Ecol. 2010, 206, 297-308. [CrossRef]

80. Lucas-Borja, M.E.; Ortega, R.; Miralles, I.; Plaza-Álvarez, P.A.; González-Romero, J.; Peña-Molina, E.; Moya, D.; Zema, A.; Wagenbrenner, J.W.; de las Heras, J. Effects of wildfire and logging on soil functionality in the short-term in Pinus halepensis M. forests. Eur. J. For. Res. 2020, 139, 935-945. [CrossRef]

81. Lucas-Borja, M.E.; Plaza-Álvarez, P.A.; González-Romero, J.; Miralles, I.; Sagra, J.; Molina-Peña, E.; Moya, D.; de las Heras, J.; Fernández, C. Post-wildfire straw mulching and salvage logging affects initial pine seedling density and growth in two Mediterranean contrasting climatic areas in Spain. For. Ecol. Manag. 2020, 474, 118363. [CrossRef]

82. García-Jiménez, R.; Palmero-Iniesta, M.; Espelta, J. Contrasting Effects of Fire Severity on the Regeneration of Pinus halepensis Mill. and Resprouter Species in Recently Thinned Thickets. Forests 2017, 8, 55. [CrossRef]

83. Robichaud, P.R.; Waldrop, T.A. A comparison of surface runoff and sediment yields from low- and high-severity site preparation burns. Water Res. Bull. 1994, 30, 27-34. [CrossRef]

84. Donato, D.C.; Fontaine, J.B.; Robinson, W.D.; Kauffman, J.B.; Law, B.E. Vegetation response to a short interval between high-severity wildfires in a mixed-evergreen forest. J. Ecol. 2009, 97, 142-154. [CrossRef]

85. Van Wilgen, B.W.; Forsyth, G.G.; De Klerk, H.; Das, S.; Khuluse, S.; Schmitz, P. Fire management in Mediterranean-climate shrublands: A case study from the Cape fynbos, South Africa. J. Appl. Ecol. 2010, 47, 631-638. [CrossRef] 
86. Richter, C.; Rejmanek, M.; Miller, J.E.D.; Welch, K.R.; Weeks, J.; Safford, H. The species diversity x fire severity relationship is hump-shaped in semiarid yellow pine and mixed conifer forests. Ecosphere 2019, 10, e02882. [CrossRef]

87. Doblas-Miranda, E.; Martínez-Vilalta, J.; Lloret, F.; Álvarez, A.; Ávila, A.; Bonet, F.J.; Brotons, L.; Castro, J.; Curiel Yuste, J.; Díaz, M.; et al. Reassessing global change research priorities in mediterranean terrestrial ecosystems: How far have we come and where do we go from here? Glob. Ecol. Biogeogr. 2015, 24, 25-43. [CrossRef]

88. Johnstone, J.F.; Allen, C.D.; Franklin, J.F.; Frelich, L.E.; Harvey, B.J.; Higuera, P.E.; Mack, M.C.; Meentemeyer, R.K.; Metz, M.R.; Perry, G.L.W.; et al. Changing disturbance regimes, ecological memory, and forest resilience. Front. Ecol. Environ. 2016, 14, 369-378. [CrossRef]

89. European Parliament. Directive 2009/147/EC on the Conservation of Wild Birds. 2009. Available online: https://eur-lex.europa.eu/eli/dir/2009/147/oj (accessed on 16 December 2020).

Publisher's Note: MDPI stays neutral with regard to jurisdictional claims in published maps and institutional affiliations.

(C) 2020 by the authors. Licensee MDPI, Basel, Switzerland. This article is an open access article distributed under the terms and conditions of the Creative Commons Attribution (CC BY) license (http://creativecommons.org/licenses/by/4.0/). 